AGH DRILLING, OIL, GAS • Vol. 32 • No. $2 \cdot 2015$

http://dx.doi.org/10.7494/drill.2015.32.2.405

\title{
Jan Macuda*
}

\section{EFFICIENCY OF DRILLING LARGE DIAMETER WELLS WITH CUTTER BITS ON SZCZERCÓW OPENCAST**}

\section{INTRODUCTION}

In Poland lignite has been produced in opencasts at various depths form 40 to $220 \mathrm{~m}$. Most opencasts are dewatered with large diameter wells, which are drilled with rotary methods involving mud and various types of bits. Due to the difficult geologic conditions relating to the presence of lignite as well as loose and low-compact Quaternary and Tertiary material in the overburden, such wells are most commonly drilled with reverse circulation and cutter bits. Standard bits are inefficient in such conditions, and no high drilling rates can be achieved. This has a significant influence on the elongated time of interaction beween drilling mud and the wellbore aquifer zone, consequently lowering the hydrodynamic parameters of the well.

For obtaining higher penetration rates in large diameter wells a new design of profiled cutter bit was worked out and drillability tests were performed to optimize the mechanical parameters of the drilling technology.

\section{INFLUENCE OF DRILLING TECHNOLOGY PARAMETERS ON PENETRATION RATE}

The quantitative influence of properties of the drilled rocks, as well as the mechanical and hydraulic parameters of drilling on the technical indices of drilling of large diameter wells has not been clearly stated $[1,14]$. The influence of weight on bit on the mechanical penetration rate in laboratory and industrial conditions has been most extensively described in literature $[8,15,16]$.

* AGH University of Science and Technology, Faculty of Drilling, Oil and Gas, Krakow, Poland

** Work performed within the statutory research program of AGH UST No. 11.11.190.555 
Laboratory experiments performed on rock blocks revealed both the linear and nonlinear character of the momentary dependance of mechanical rate of penetration on the axial weight on bit in the form:

$$
v_{0}=A \cdot\left(P-P_{0}\right)
$$

where:

$A$ - function depending on rotary speed of bit, physico-mechanical properties of rock and hydraulic parameters of flushing the bottomhole.

$P$ - weight on bit,

$P_{0}$ - weight on bit corresponding to the transition from surface drilling to bulk drilling,

or in the power form:

$$
v_{0}=A \cdot P_{a}
$$

where $a$-influence of weight on bit on mechanical rate of penetration.

Another mechanical parameter of drilling is the rotary speed of bit. Its influence on the momentary mechanical rate of penetration has been well recognized. The analysis of literature $[2,7,9]$ reveals that the influence of rotary speed is linear to some value; after exceeding it the plot declines to the right proving that the bottomhole was flushed inefficiently. Most of the mathematical dependances describing the influence of rotary speed on the rate of penetration (with the remaining parameters stable), have the following form:

$$
v_{0}=B \cdot n^{b}
$$

where:

$B$ - function depending on the weight on bit, physico-mechanical properties of rock and hydraulic parameters of flushing,

$n$ - rotary speed of the bit,

$b$ - coefficient of rotary speed of bit on mechanical rate of penetration.

The dependance of momentary mechanical rate of penetration on mechanical parameters of drilling can be described with a general formula:

$$
v_{0}=Z \cdot P^{a} \cdot n^{b}
$$

where $Z$ - coefficient of drillability.

Coefficient of drillability $Z$ is always positive and describes the bit/rock system in the process of drilling. The higher is its value the more easily the rock can be drilled and the higher can be the rate of penetration. The influence of the weight on bit and rotary speed of drilling of large diameter wells was best described in literature $[14,15]$. Depending on the properties of drilled rocks the value of power $a$ changes from 0.6 to 2.3 , and exponent $b$ from 0.1 to 1.0 .

The value of the momentary mechanical rate of penetration is also significantly influenced by the hydraulic parameters of the wellbottom flushing [13, 22, 23]. The analysis of 
the obtained results revealed that the increase of mud density, solid phase content in mud, dispersion level and increase of kinematic viscosity result in a lower rate of penetration. However, it will increase with the growing mud filtration.

\section{DRILLABILITY TEST WITH THE CUTTER BIT}

Among the most important factors having influence of high mechanial rates of penetration are the correct type of bit as well as optimum mechanical and hydraulic parameters of drilling $[5,12,15]$.

For the sake of increasing the rate of penetration when drilling large diameter wells a new cutter bit design was worked out and then tested for its drillability properties on Szczerców opencast. The industrial tests were performed on a cutter bit $0.96 \mathrm{~m}$ in diameter. The wells were drilled with a rig Wirth B3A.

For establishing optimum mechanical parameters of drilling the drillability tests were performed for the following assumptions:

- bit cycle in macroscopicaly homogeneous rocks,

- type of bit adjusted to the type of drilled rock,

- weight on bit and its rotary speed are constant,

- weight on bit and its rotary speed are constant and belong to a set of admissible decisions resulting from the technical characteristic of the rig.

The drillability tests were conducted on a geological profile in the Szczerców field where macroscopically homogeneous layers (i.e. similar drillability for a definite type and kind of bit) were selected. This is an important issue for the selection of optimum parameters of drilling as the change of the lithology of the drilled rocks does not have to go with the change of their drillability; rocks bearing the same name may have different drillability [20, 21].

The following macroscopically homogeneous layers were distinguished in the Quaternary and Tertiary formations based on literature [11, 19]:

$\mathrm{W}_{1}$ - sands and gravel,

$\mathrm{W}_{2}$ - lignite and sapropelite,

$\mathrm{W}_{3}$ - clays, silt, mudstone.

Prior to the drillability tests, limitations for the mechanical parameters of drilling technology were established taking into account the technical characteristic of the rig Wirth B3A, i.e.:

$$
\begin{aligned}
& P \in\left(P_{\text {min }} ; P_{\text {max }}\right) \\
& n \in\left(n_{\text {min }} ; n_{\text {max }}\right)
\end{aligned}
$$

where:

$P_{\text {min }}, P_{\text {max }}-$ minimum and maximum value of weight on bit,

$n_{\min }, n_{\max }-$ minimum and maximum value of rotary speed of bit. 
Then, taking into account the assumed limitations (5) and (6), five measuring points were assumed for the drillability tests [6,7], where the planned sections of the well were drilled. The final point of the drillability test always coincided with the initial one. This was done to verify whether or not the well was drilled in the same macroscopically homogeneous layers. An assumption was made that the well was drilled in the same conditions, provided the rates of penetration at points 1 and 6 did not differ more than by $10-15 \%$.

The drillability tests with the new cutter bit $0.96 \mathrm{~m}$ in diameter were performed for the following parameters of drilling:

- weight on bit

- rotary speed of bit

- mud volume

- mud flow rate inside the string

$$
\begin{aligned}
& 1.47-2.45 \cdot 10^{4} \mathrm{~N}, \\
& 0.25-1.0 \mathrm{~s}^{-1}, \\
& 0.077 \mathrm{~m}^{3} / \mathrm{s}, \\
& 4.3 \mathrm{~m} / \mathrm{s} .
\end{aligned}
$$

Depending on the planned thickness of the drilled layer, the following lengths of measurement sections were determined: $0.3 ; 0.4 ; 0.5$ and $1.0 \mathrm{~m}$. Each of the measurement sections was drilled at constant rotary speeds and weights on bit.

The drillability tests were carried out while drilling eight wells in the Szczerców field with a rig Wirth B3A.

\section{RESULTS AND DISCUSSION}

For the sake of finding the dependance between the mechanical rate of penetration and weight on bit for selected layers $\mathrm{W}_{1}, \mathrm{~W}_{2}$ and $\mathrm{W}_{3}$, various regression models were analyzed $[\mathrm{C} 3,4]$. The most satisfactory results were obtained for a power model of influence of weight on bit and rotary speed of bit on the rate of penetration. The regression coefficients and statistical parameters confirm a very good fit of the model to measurement data presented in Tables $1-4$.

The average rate of penetration for the cutter bit with profiled blades was described with the following formula:

$$
V_{a v}=Z \cdot P^{n} \cdot n^{b}
$$

where:

$V_{a v}$ - average rate of penetration,

$Z$ - drillability coefficient,

$P$ - weight on bit,

$n$ - rotary speed of bit,

$a$ - coefficient of impact of weight on bit on the rate of penetration,

$b-$ coefficient of impact of rotary speed on the rate of penetration.

For the sake of analyzing the power model of impact of weight on bit and rotary speed of bit equation (7) was logarithmized and then transformed by sides to a linear equation:

$$
\ln V=\ln Z+a \cdot \ln P+b \cdot \ln n
$$

The regression coefficients for model (8) and their statistical significance were calculated on the basis of computer software STATISTICA - multiple regression $[10,17,18]$. 
The most important parameter defining a good fit of the model is coefficient of determination $R^{2}$. This coefficient gives information which part of the general variability of dependent variable is explained by the regression and will assume values from 0 to 1 . The closer is $R^{2}$ value to unity, the better fit of the model is obtained. The analysis of the obtained results for particular macroscopically homogeneous layers reveals that the model fits very well.

The corrected $R^{2}$ was also accounted in the analysis. It determines the fit of the regression equation to another sample of the same population. Its value is always lower than that of $R^{2}$.

The analyzed statistics have been used for verifying the hypothesis that the regression coefficients are not equal to 0 .

The error of estimate of model defined how much the constant value can differ from the calculated one.

Tables 1-3 contain a list of coefficients of equation of average mechanical rate of penetration and also parameters verifying the statistical correctness of the model:

- population of samples,

- standard error of regression coefficients,

- $t$ Student test values for particular regression coefficients,

- significance level for particular regression coefficients,

- multiple correlation coefficient $R$,

- coefficient of determination $R^{2}$,

- corrected coefficient of determination $R^{2}$

- $F$-distribution and probability level $p$,

- standard error of estimate.

Table 1

Parameters of equation of average rate of penetration with cutter bit having profiled wings $\varnothing 0.96 \mathrm{~m}$ in layers $\mathrm{W}_{1}$

\begin{tabular}{|c|c|c|c|c|}
\hline Dependent parameter & $\begin{array}{l}\text { Regression } \\
\text { coefficient }\end{array}$ & $\begin{array}{l}\text { Standard error } \\
\text { of regression } \\
\text { coefficient }\end{array}$ & $\begin{array}{c}\text { Value of } \\
t \text { Student test }\end{array}$ & $\begin{array}{c}\text { Significance } \\
\text { level }\end{array}$ \\
\hline Absolute term $\ln Z$ & -2.11619 & 0.222816 & -9.49750 & 0.000000 \\
\hline$a$ & 0.42392 & 0.022228 & 19.07124 & 0.000000 \\
\hline$b$ & 0.26199 & 0.017119 & 15.30453 & 0.000000 \\
\hline \multicolumn{5}{|c|}{ Number of measurements $N=47$} \\
\hline \multicolumn{5}{|c|}{ Absolute term $Z=0.1204898$} \\
\hline \multicolumn{5}{|l|}{$R=0.96478375$} \\
\hline \multicolumn{5}{|l|}{$R^{2}=0.93080768$} \\
\hline \multicolumn{5}{|c|}{ Coefficient of determination $R^{2}=0.92766257$} \\
\hline \multicolumn{5}{|c|}{$F$-distribution $(2.44)=295.95, \quad p<0.0000$} \\
\hline \multicolumn{5}{|c|}{ Standard error of estimate $=0.03764$} \\
\hline
\end{tabular}


Table 2

Parameters of equation of average rate of penetration with cutter bit having profiled wings $\varnothing 0.96 \mathrm{~m}$ in layers $\mathrm{W}_{2}$

\begin{tabular}{|c|c|c|c|c|}
\hline $\begin{array}{c}\text { Dependent } \\
\text { parameter }\end{array}$ & $\begin{array}{c}\text { Regression } \\
\text { coefficient }\end{array}$ & $\begin{array}{c}\text { Standard error } \\
\text { of regression } \\
\text { coefficient }\end{array}$ & $\begin{array}{c}\text { Value of } \\
t \text { Student test }\end{array}$ & $\begin{array}{c}\text { Significance } \\
\text { level }\end{array}$ \\
\hline Absolute term $\ln Z$ & -2.91148 & 0.228494 & -12.7421 & 0.000000 \\
\hline$a$ & 0.51179 & 0.42392 & 22.3004 & 0.000000 \\
\hline$b$ & 0.16888 & 0.023458 & 7.1992 & 0.000000 \\
\hline
\end{tabular}

Number of measurements $N=57$

Absolute term $Z=0.054395$

$R=0.95362239$

$R^{2}=0.90939566$

Coefficient of determination $R^{2}=0.90603994$

$F$-distribution $(2.54)=271.00, p<0.0000$

Standard error of estimate $=0.04813$

Table 3

Parameters of equation of average rate of penetration with cutter bit having profiled wings $\varnothing 0.96 \mathrm{~m}$ in layers $\mathrm{W}_{3}$

\begin{tabular}{|c|c|c|c|c|}
\hline $\begin{array}{l}\text { Dependent } \\
\text { parameter }\end{array}$ & $\begin{array}{l}\text { Regression } \\
\text { coefficient }\end{array}$ & $\begin{array}{l}\text { Standard error } \\
\text { of regression } \\
\text { coefficient }\end{array}$ & $\begin{array}{c}\text { Value of } \\
t \text { Student test }\end{array}$ & $\begin{array}{c}\text { Significance } \\
\text { level }\end{array}$ \\
\hline Absolute term $\ln Z$ & -1.64557 & 0.274714 & -5.99012 & 0.000000 \\
\hline$a$ & 0.39188 & 0.028537 & 13.73201 & 0.000000 \\
\hline$b$ & 0.23652 & 0.024467 & 9.66697 & 0.000000 \\
\hline \multicolumn{5}{|c|}{ Number of measurements $N=60$} \\
\hline \multicolumn{5}{|c|}{ Absolute term $Z=0.192902577$} \\
\hline \multicolumn{5}{|l|}{$R=0.89671485$} \\
\hline \multicolumn{5}{|l|}{$R^{2}=0.80409753$} \\
\hline \multicolumn{5}{|c|}{ Coefficient of determination $R^{2}=0.79722376$} \\
\hline \multicolumn{5}{|c|}{$F$-distribution $(2.54)=116.98, p<0.0000$} \\
\hline \multicolumn{5}{|c|}{ Standard error of estimate $=0.04635$} \\
\hline
\end{tabular}


Table 4 gives a list of average model rates of penetration $a, b$ and $Z$ for selected macroscopically homogeneous layers $\mathrm{W}_{1}, \mathrm{~W}_{2}$ and $\mathrm{W}_{3}$ which were determined during the tests.

\section{Table 4}

Values of coefficients $Z, a$ and $b$ for a model of average rate of penetration with cutter bits having profiled wings

\begin{tabular}{|c|c|c|c|c|}
\hline \multirow{2}{*}{$\begin{array}{c}\text { Bit diameter } \\
{[\mathrm{m}]}\end{array}$} & \multirow{2}{*}{$\begin{array}{c}\text { Type of } \\
\text { macroscopically } \\
\text { homogeneous } \\
\text { layer }\end{array}$} & \multicolumn{3}{|c|}{ Coefficients } \\
\hline & & $Z$ & $a$ & $b$ \\
\hline \multirow{3}{*}{0.96} & $\mathrm{~W}_{1}$ & 0.1204898 & 0.42392 & 0.26199 \\
\hline & $\mathrm{W}_{2}$ & 0.054395 & 0.51179 & 0.16888 \\
\hline & $\mathrm{W}_{3}$ & 0.192902577 & 0.39188 & 0.23652 \\
\hline
\end{tabular}

Basing on the model of average rate of penetration some industrial tests were performed to assess the efficiency of drilling large diameter dewatering wells with a cutter bit with profiled blades $0.96 \mathrm{~m}$ of diameter. The wells were drilled with a rig Wirth B3A and depending on the type of drilled rocks the following drilling parameters were used:

- inner diameter of the string

$0.145 \mathrm{~m}$,

- weight on bit

$1.47-2.94 \cdot 10^{4} \mathrm{~N}$

- rotary speed of bit

$0.25-1.0 \mathrm{~s}^{-1}$

- volume of mud

$0.077 \mathrm{~m}^{3} / \mathrm{s}$,

- mud flow rate inside the string

$4.3 \mathrm{~m} / \mathrm{s}$.

The average rates of penetration obtained while performing industrial tests ranged between $9.72 \times 10^{-4}$ to $3.61-10^{-3} \mathrm{~m} / \mathrm{s}$ and were higher than the ones obtained so far, i.e. from 211.42 to $297.31 \%$.

\section{CONCLUSIONS}

1. The model of average rate of penetration for newly designed cutter bits will allow for increasing the efficiency of drilling of large diameter dewatering wells in difficult geologic conditions.

2. In industrial practice the optimum mechanical parameters of drilling should be selected accounting for the limitations relating to the weight on bit and rotary speed of bit.

3. While drilling wells with cutter bits of larger diameter, attention should be paid to additional limitations resulting from the technical characteristic of the rig and the string. 


\section{REFERENCES}

[1] Bernt S., Adnoy A.: Modern wells and design. A.A. Balkema, Rotterdam, Netherlands, 1996.

[2] Besson A., Toutain P., Meany N.: Improved BHAs, bits optimize drilling performance. Drilling Contractors, vol. 49, nr 1, 1993.

[3] Cobb G.W.: Introduction to Design and Analysis of Experiments. Springer, New York 1998.

[4] Dobosz M.: Wspomagana komputerowo statystyczna analiza wyników badań. EXIT, Warszawa 2001.

[5] Dimitrijevič B.: Optimization of hole mining parameters exemplified by underlying sands at the „Polje-D” open pit mine in Kolubara. M.A. thesis, Faculty of Mining and Geology, Belgrade 2000.

[6] Dimitrijevic B., Pinka J., Mitrovic V.: Selection of technological parameters in borehole mining production by technical deep drilling and hydroexploitation. Acta Montanistica Slovaca, Ročník 9, číslo 3, 2004.

[7] Gonet A.: Calculation of optimum time of drilling the hole with cutter bit. Archiwum Górnictwa, vol. 37, z. 3, 1992.

[8] Gonet A.: Optymalizacja mechanicznych parametrów technologii wiercenia otworów świdrami skrawajacymi. Przegląd Górniczy, nr 5, 1995.

[9] Gonet A., Macuda J., Stryczek S., Czekaj L.: Environmental Applications of Large Diameter Wells. $5^{\text {th }}$ International Symposium on the Reclamation, Treatment and Utilization of Coal Mining Wastes. $3^{\text {th }}$ Conference on Environment and Mineral Processing, 10-13 September 1996, VŚB-TU Technical University Ostrawa, Czech Republic.

[10] Greń J.: Statystyka matematyczna. Modele i zadania. Wydawnictwo PWN, Warszawa 1999.

[11] Kidybiński A.: Podstawy geotechniki kopalnianej, Wydawnictwo Śląsk, Katowice 1982.

[12] Macuda J.: Analiza technicznych wskaźników wiercenia wielkośrednicowych otworów odwadniajacych na złożu KWB Bełchatów. Zeszyty Naukowe AGH Górnictwo, R. 19, z. 2, 1995, 121-129.

[13] Macuda J.: Reverse Circulation Air Lift Methods for Big Hole Drilling in BrownCoal Mines. $9^{\text {th }}$ International Scientific and Technical Conference „New Knowledges in Sphere of Drilling, Production and Gas Storages" Technical University Kosice, Kosice 8-10 October 1996, Slowak Republic.

[14] Macuda J.: Analysis of Efficiency of Drilling of Large-diameter Wells with a Profiled Wing Bit. Archives of Mining Sciences, vol. 57, No. 2, 2012.

[15] Miska S.: Identyfikacja procesu wiercenia narzędziami skrawajacymi. Archiwum Górnictwa, vol. 2, z. 3, 1975. 
[16] Perry P.B., Curry D.A., Kerridge J.D., Lawton J.: A Case Based Knowledge Repository for Drilling Optimization. IADC/SPE Asia Pacific Drilling Technology Conference and Exhibition, 13-15 September 2004, Kuala Lumpur, Malaysia.

[17] Podręcznik użytkowania pakietu statystycznego „Statystyka”. StatSoft, Kraków 2005.

[18] Stanisz A.: Przystępny kurs statystyki z zastosowaniem STATISTICA PL na przyktadach z medycyny. Wyd. StatSoft Polska, Kraków 2007.

[19] Wiłun Z.: Zarys geotechniki. Wyd. WKiŁ, Warszawa 2003.

[20] Wiśniowski R.: Dobór typów świdrów gryzowych do rodzaju przewiercanych skat. Cz. 1. NTTB Nowoczesne Techniki i Technologie Bezwykopowe, nr 2, 1999.

[21] Wiśniowski R.: Dobór typów świdrów gryzowych do rodzaju przewiercanych skat. Cz. 2. NTTB Nowoczesne Techniki i Technologie Bezwykopowe, nr 3, 1999.

[22] Wiśniowski R., Stęperski P.: Wpływ parametrów reologicznych modelu Herschela-Bulkleya na wynoszenie zwiercin. Nafta-Gaz, t. 25, z. 2, 2007.

[23] Wiśniowski R., Stryczek S., Skrzypaszek K.: Kierunki rozwoju badań nad reologia płynów wiertniczych. Wiertnictwo, Nafta, Gaz, t. 24 z. 1, 2007, 595-607. 